\title{
Down syndrome: the prevalence of Alzheimer's disease and the role of thyroid hormone
}

\author{
GISELE GIANNOCCO \\ Universidade Federal de São Paulo (Unifesp), Diadema, SP, Brasil. \\ E-mail: ggiannocco@gmail.com
}

\begin{abstract}
ANDRÉA VANCETTO MAGLIONE
Universidade Federal de São Paulo (Unifesp), Diadema, SP, Brasil.

E-mail: andrea@maglione.com.br

JÉSSICA SALLES HENRIQUE

Universidade Federal de São Paulo (Unifesp), Diadema, SP, Brasil.

E-mail: je.salles@yahoo.com
\end{abstract}

\author{
JANAINA SENA DE SOUZA \\ Universidade Federal de São Paulo (Unifesp), Diadema, SP, Brasil. \\ University of California, San Diego, La Jolla, USA. \\ E-mails: ninasenasouza@gmail.com
}

\begin{abstract}
Trisomy of chromosome 21 causes Down syndrome (DS) and affects around 1 in 700 live births in the USA and 11.2 in 10,000 live births in Europe. For about a century, the birth of individuals with DS was associated with advanced maternal age and now the cases of late motherhood are becoming more common. DS is the most common genetic disorder that causes intellectual disability; and advancements in science in developed countries have made it possible for people affected by this syndrome to live longer, but an extended life span has brought with it Alzheimer's disease (AD), which exacerbates the cognitive decline in these individuals. The onset of $\mathrm{AD}$ occurs much earlier in DS individuals than in the general population. $\mathrm{AD}$ is a severe progressive neurodegenerative disease, which induces decreasing memory capacity and cognition. Several important genes related to AD are
\end{abstract}

\footnotetext{
1 This study was supported by the Fundação de Amparo à Pesquisa do Estado de São Paulo to Gisele Giannocco (Fapesp \#2017/23169-1) and to Janaina Sena de Souza (Fapesp \#2017/07053-3; \#2018/22763-0).
} 
overexpressed in DS due to the extra chromosome. The production of hormones that are very important to the development of the central nervous system, such as thyroid hormones, is affected by DS. Patients with AD have been reported to present changes in the homeostasis of thyroid hormones. In order to understand $\mathrm{AD}$ in $\mathrm{DS}$ and try to find ways to improve the quality of life of these individuals, the understanding of these three conditions, $\mathrm{DS}, \mathrm{AD}$, and $\mathrm{TH}$ homeostasis, is central to finding better treatments and improving patient well-being.

\section{Keywords}

Down syndrome. Alzheimer's disease. Thyroid hormone.

\section{INTRODUCTION}

Reports of Down syndrome (DS) date back to $1500 \mathrm{BC}$ and are evidenced by paintings found in the Oxtotitlan cave located near Chilapa, Mexico. Individuals with DS were venerated in Olmec culture since they were thought to be descendants of humans and jaguar (PUESCHEL, 1998). The first clinical description of a child with DS was made by Jean-Étienne Dominique Esquirol in 1838, but a more consistent clinical description, by Langdon Down, would take almost another thirty years. And it wasn't until 1959 that the existence of the extra copy of chromosome 21 (HSA21) was found in these individuals (HEAD et al., 2016).

DS is the genetic manifestation of trisomy of chromosome 21, that causes behavioral alterations and intellectual disabilities throughout the lifespan; other medical issues appear in high frequency, such as endocrinopathies, heart defects, pneumonia, feeding problems as duodenal atresia, constipation, congenital hearing loss (BULL; COMMITTEE ON GENETICS, 2011; WHOOTEN et al., 2018). In the United States, the frequency of DS is approximately 1 in 750 and 1 in 691 live births (ROPER; REEVES, 2006; PARKER et al., 2010, DE GRAAF et al., 2015, 2017), while in Europe the frequency is 11.2 for every 10,000 births (GLIVETIC et al., 2015).

One of the causes linked to DS is the biological age of the mother and a marked decrease in the telomere length of the woman who gives birth to a child with DS. This shortening of the telomere is due to external factors, such as tobacco consumption (RAY et al., 2016). At the age of 20, the risk of genetic abnormalities is $0.5 \%$. The risk doubles at 35 years of age, and increases to 
$2 \%$ at the age of 37 , reaching $5 \%$ in a woman's early 40 s and $10 \%$ at 44 . The main anomaly is DS, but there are also Edwards and Patau syndromes, among others.

Therefore, several countries show trends over two decades in the number of DS fetuses conceived, which is increased proportionally to the rising age of a pregnancy (ROIZEN; PATTERSON, 2003).

DS life expectancy increased from a median age of 4 in the 1950s to 58 in 2010 and presents an important public health challenge, since the survival of children born with this condition depends on special medical care to diseases, which appear in later life, social and educational treatment and this care is required for life (GLIVETIC et al., 2015; DE GRAAF et al., 2017). Individuals with DS have high rates of thyroid dysfunction (TD), among them congenital hypothyroidism $(\mathrm{CH})$, subclinical hypothyroidism ( $\mathrm{SCH}$ ), Hashimoto's autoimmune disease (HD) and Graves' disease (GD) (BULL; COMMITTEE ON GENETICS, 2011; WHOOTEN et al., 2018). Patients with DS are more vulnerable to both hypothyroidism and Alzheimer's disease (AD), which may be associated with an increase in the concentration of thyroid-stimulating hormone (TSH), which indicates that TSH might be neurotoxic (BHAUMIK et al., 1991). Elevated TSH levels in the presence of normal circulating T4 and T3 can indicate Subclinical hypothyroidism or borderline hypothyroidism (BHAUMIK et al., 1991; BÉGIN et al., 2008). In this way, studying conditions, such as AD, which appears throughout the life of these individuals, is fundamental for the eventual improvement of their quality of life.

Cognitive deficiency, a hallmark of the trisomy 21 patient, is present at all stages of life and worsens with age. The degree can vary from one person to another, depending on the penetrance of the syndrome. The worsening of cognitive impairment has already been described in middle age, and this alteration was later shown to be due to the early onset of AD (PAGANO; CASTELLO, 2012; HEAD et al., 2016). Adults with DS invariably develop senile plaques composed of the $\beta$-amyloid peptide $(A \beta)$, which are not differentiated from sporadic $\mathrm{AD}$ upon histopathological examination and are at high risk for early development of dementia (HEAD et al., 2016).

In addition, the DS patient may present changes in the thyroid (hypothyroidism) and carbohydrate (type 2 diabetes) metabolism (PAGANO; CASTELLO, 2012). Hypothyroidism is found in a high percentage in trisomy 21, so thyroid function evaluation is part of the follow-up guidelines for children and adults who have the chromosome 21 trisomy (VIRJI-BABUL et al., 2007). 


\section{ALZHEIMER'S DISEASE}

Between 2000 and 2010, there was a 68\% increase in AD cases, a significant number for a relatively short period (ALZHEIMER'S ASSOCIATION, 2013).

$\mathrm{AD}$ is a severe and non-reversible progressive neurodegenerative disease, which begins years before its clinical manifestation. This disease causes the dysfunction and deterioration of the neurons in the cortical region, inducing the loss of memory and the progressive decline of cognition, as well as reduced brain volume (CORREIA et al., 2012; SULLIVAN; YOUNG-PEARSE, 2017). AD can be genetic in origin, affecting 1\% of people between 30 and 60 years of age and this type is known as early-onset (occurring in an early stage of life); there is also sporadic $\mathrm{AD}$, which affects more than $40 \%$ of people over 85 years of age (REITZ et al., 2011).

Histopathology of AD presents:

- Deposit of extracellular amyloid plaques and formation of senile plaques, which are derived from amyloid $\beta$ peptides. The most common type of amyloid $\beta$ peptides produced in $\mathrm{AD}$ is $\mathrm{A} \beta 42$, which is more toxic and has higher aggregation potential (HEAD et al., 2016).

- Neurofibrillary tangles, which are intracytoplasmic aggregates and paired helical filaments, composed of hyperphosphorylated and insoluble tau microtubulin protein groups (KUMAR et al., 2015).

- Neurodegeneration and loss of synapses, which are caused by oxidative stress, changes in calcium homeostasis, caused by dysfunctional mitochondria (WANG et al., 2014) and disruptions of homeostasis of glucose-energy and lipid metabolism (SATO; MORISHITA, 2015).

The mutation in the genes coding for amyloid precursor protein (APP), apolipoprotein (ApoE), and presenilin 1 and 2 (PSEN1 and PSEN2) are usually associated with the onset of $\mathrm{AD}$ (KIM et al., 1999).

Metabolic degeneration may also be associated with $\mathrm{AD}$, since insulin has targets in some regions of the central nervous system (CNS), such as the hippocampus and frontal cortex, insulin mediating a variety of effects, including cognition and memory (SALAMEH et al., 2016).

The treatments that currently exist for $\mathrm{AD}$ are only palliative, since the disease does not have a cure. Two classes of drugs, acetylcholinesterase in- 
hibitors and N-methyl-D-aspartate (NMDA) receptor modulators, are drugs that maximize neurotransmitter productivity and are either temporary or of medium impact on their effects (SULLIVAN; YOUNG-PEARSON, 2017). Therefore, finding new treatments for $\mathrm{AD}$ is fundamental, since the number of individuals suffering from this disease has grown rapidly.

\section{ALZHEIMER'S DISEASE IN DOWN SYNDROME}

The increased risk for $\mathrm{AD}$ in the $\mathrm{DS}$ population has become an important concern, since the life expectancy for people with DS has increased over the past 30 years. The excessive production of amyloid plaques and neurofibrillary tangles occurs due to the overexpression of the gene encoding for the APP, which is located on chromosome 21 (LOTT; HEAT, 2019).

DS patients may develop AD about 2 to 3 decades before the general population. Thus, approximately 5\%-15\% of DS patients between $40-49$ years of age and more than $30 \%$ of those between $50-59$ years of age have a significant decline in cognitive function, presenting dementia; at 65 years of age, about $68 \%-80 \%$ of DS patients develop dementia and more than $50 \%$ will develop AD in their lifetimes (PENNINGTON et al., 2003; ALZHEIMER'S ASSOCIATION, 2018).

In DS, the APP gene is tripled since it is located on chromosome 21. Moreover, other genes encoded by chromosome 21 are more associated with cognitive worsening than APP (CARMONA-IRAGUI et al., 2019). Therefore, DS is a genetic example of increased production of $A \beta$, making this group interesting for the study of AD (ANNUS et al., 2016). $\beta$-secretase has been identified as beta-site APP cleaving enzyme or BACE1 and its activity increases with age, which may increase A $\beta$ accumulation, since, in this syndrome, APP is also overexpressed up to 1.5 fold compared to individuals without trisomy 21 (HEAD et al., 2016). Another gene located on chromosome 21 is BACE2, which has great homology with BACE1 and also cleaves APP (HEAD et al., 2016).

The appearance of senile plaques and neurofibrillary tangles can occur very early in the life of people with DS, for example, the appearance of amyloid-beta (A $\beta$ ) -peptide accumulation can be observed with immunohistochemistry technics in the hippocampus of dead DS patients as early as 8 to 12 years of age (LEVERENZ; RASKIND, 1998). However, the age of onset of dementia varies from one individual to another, which may point to other factors besides the tripling of APP (MOK et al., 2013). Several genes present on chromosome 
21 are indicated as modulators of AD onset in DS. but other studies will be needed to determine their role and importance (HEAD et al., 2016). It is estimated that more than 550 genes are expressed on chromosome 21 and that more than 160 of these genes encode known proteins (ALLDRED et al., 2015; STURGEON; GARDINER, 2011). APP, which is overexpressed in DS and AD, are related to the inhibition of cell proliferation (CATALDO et al., 2000; WU et al., 2016), as well as BACE2, one of the isoforms that cleaves the amyloid precursor protein (MOK et al., 2013; VASSAR et al., 2014).

Oxidative stress is an important feature in DS and may contribute to the damage caused in the nervous tissue, which can lead to AD. Genes related to oxidative stress are also located on chromosome 21, such as CuZn superoxide dismutase (SOD1), transcription factor Ets-2, S100B, and carbonyl reductase, that are part of the most relevant contributors for oxidative stress (PERLUIGI et al., 2014). Bach1 protein also seems to be present in high levels in the brains of individuals with DS, indicating repression of HO-1 (heme oxygenase-1) transcription, which increases oxidative stress in trisomy 21 (DI DOMENICO et al., 2015).

Other studies have already shown that dual-specificity tyrosine phosphorylation-regulated kinase 1A (Dyrk1A) and the regulator of calcineurin 1 (RCAN1), which are two genes also found on chromosome 21, are related to the early onset of $\mathrm{AD}$ in individuals with DS. Dyrk1A interacts directly with RCAN1, phosphorylating it, which enhances the ability of RCAN1 to reduce calcineurin phosphorylation (Caln), leading to reduced nuclear factor of activated $\mathrm{T}$ cells and increasing the phosphorylation of the tau protein, which is related to AD (JUNG et al., 2011; SUN et al., 2011). This suggests a correlation between Caln-NFAT signaling and Tau hyperphosphorylation and might explain a variety of pathological features associated with DS (JUNG et al., 2011).

\section{THYROID HORMONES AND ENERGY HOMEOSTASIS IN THE BRAIN}

The brain is an important target organ for the action of thyroid hormones (TH), including 3,5,3-triiodothyronine (T3), the most active form, and thyroxine (T4), TH poorly active precursor (FLAMANT et al., 2017). During brain maturation, THs influence the processes of development, differentiation, myelination, cytoskeletal stabilization and signaling of neurons and glia (MENDESDE-AGUIAR et al., 2008). The genes involved in this process are regulated for 
THs that act mainly in the nucleus, where chromatin-associated thyroid hormone receptors (TR) are present (BERNAL, 2007). The transport of maternal THs for fetus across the placenta has an important role around 16-20 weeks of gestational age, when there is not fetal thyroid function, but there are TR in the fetal brain, and on this, maternal TH production increases by approximately 50\% (MOOG et al., 2015). Several studies observed that children of mothers with hypothyroidism show a lower IQ and problems with selective attention and memory, and their performance was strongly correlated with maternal TSH levels during pregnancy (ROVET, 2014). A study with 416 women with TD did not show an increase in the risk of TD on maternal age over 30 (DIÉGUEZ et al., 2015). In another study developed in Denmark, but now about smoking in pregnancy, the conclusion was that smoking increased the risk of hyperthyroidism and decreased the risk of hypothyroidism (ANDERSEN et al., 2014).

T4, T3, and rT3 enter the brain via specific transporters (FRIESEMA, 2005). The monocarboxylate transporter (MCT) family of transporters has up to 14 members, some of which are involved in transporting important substrates to the brain. In humans, MCT8 appears to have greater importance in the CNS and might be involved in neuronal thyroid hormone transport mechanisms, thus, the lack of MCT8 results in great neuronal damage (HEUER, 2007). The T4-binding protein, transthyretin (TTR), has been implicated in the transport of TH through the cerebral circulation and its blood-brain barrier and may be involved in the delivery of cerebrospinal fluid thyroid hormone to the brain (PATEL et al., 2011).

Once transported into the cell, T4 is converted into T3 by type 2 deiodinases mainly present in glial cells, astrocytes, and ependymal cells, although the main target of this hormone is the neurons that have specific receptors for THs (MORTE; BERNAL, 2014). The actions of THs are based on the interaction of T3 with receptors located in specific regions of the DNA, known as TH responsive elements (TREs), located in the regulatory region of the T4 or T3 target genes. The interaction of the TH/nuclear receptor (TR) complex with TREs leads to the activation or inhibition of specific gene transcription and the synthesis of the proteins they encode (HARVEY; WILLIAMS, 2002).

It has been observed that in TD in adults, particularly in hypothyroidism, there are deficits in cognitive functions that are reversible with hormone replacement (DE SOUZA et al., 2016; ZHANG et al., 2012). However, magnetic 
resonance imaging studies correlate hyperthyroidism with decreased hippocampus and amygdala volumes and the onset of dementia (DE JONG et al., 2006), while other studies have associated prolonged use of T4 with the onset of $\mathrm{AD}$, once $\mathrm{TH}$ can regulate the generation of APP isoforms (HARPER; ROE, 2010).

Davis et al. (2008) found that tissue from biopsies of patients with $A D$ showed a decrease in T3 levels with no change in T4 concentration in the prefrontal lobe, suggesting the involvement of deiodinases in the pathology and clinical presentation of the disease.

At the cellular level, THs down-regulate the transcription of the APP. Knockout mice for TH receptors show an increase in APP messenger RNA (CONTRERAS-JURADO; PASCUAL, 2012). Treatment with T4 caused a decrease in cognitive impairment and improvement in behavioral tests that evaluate memory in animal models of $\mathrm{AD}$; this might occur by the decrease of free radicals and inhibition of neuronal apoptosis (FU et al., 2010).

The metabolic abnormalities that arise in the mitochondria in $\mathrm{AD}$ are the result of the oxidative damage that upregulates genes related to mitochondrial metabolism and apoptosis (LIN; BEAL, 2006; BUTTERFIELD; HALLIWELL, 2019). Thus, at the beginning of $A D$, the use of glucose is reduced by $45 \%$, and this parameter is aggravated at an advanced stage of the disease (BERGER, 2016). The metabolism of glucose is supposed to be affected by a decrease in the activity of mitochondria, characterized by an alteration in the activity of some enzymes, among which the following stand out: pyruvate dehydrogenase, dehydrogenase isocitrate and $\alpha$-ketoglutarate dehydrogenase. Glucose consumption is decreased before the onset of signs and symptoms of the pathology (CORREIA et al., 2012).

The change in glucose homeostasis has also been reported as one of the possible causes of $\mathrm{AD}$. A high glucose concentration can be toxic to the neurons, causing osmotic insults and oxidative stress. In addition, continuous maintenance of chronic high glucose concentration leads to the formation of advanced glycation endoproducts (AGEs), which potentiate toxic effects in neurons. AGEs, in turn, interact with free radicals and create oxidative damage, which can lead to neuronal damage. These metabolites can still react with the microglia, making it deleterious. Such a condition is involved in the pathophysiology of neurodegenerative diseases, including AD (UMEGAKI, 2012; LIU et al., 2015). 
In this context, insulin signaling in the CNS prevents the pathogenic binding of $A \beta$ oligomers. The agonist of PPAR-gamma, an insulin sensitizer with anti-inflammatory functions, may present relevant roles in $\mathrm{AD}$ with a protective neural effect (KAPADIA et al., 2008). In patients in the initial phase of AD, one study showed that the use of nasal insulin had some benefit, improving memory and attention, without affecting plasma glucose (REGER et al., 2006). However, other studies have shown that insulin accelerates AD-related pathology, since it affects $A \beta$ metabolism and tau phosphorylation. Moreover, insulin resistance alters the synthesis of several proteins, including those related to the pathophysiology of AD (UMEGAKI, 2012).

\section{CONCLUSION}

DS is present in a significant number of individuals in the population with similarities with late-onset $\mathrm{AD}$. These individuals, due to advancements in medicine and follow-up with specialists, are living longer, increasing the prevalence of $\mathrm{AD}$ as the life expectancy of patients with trisomy 21 rises. Chromosome 21 is responsible for the expression of genes classically related to $A D$ (APP, BACE2) and also for the expression of genes related to oxidative stress (SOD-1, RCAN1), which leads to damage to the CNS and may result in AD. Different gene expressions led to responding differently to conventional treatment. Genetic studies are necessary to develop new drugs for these approaches. Analogs to TH can play a part in these approaches.

$\mathrm{TH}$, important to the development of the nervous system and maintenance of this tissue throughout life, may also be involved in the development of $\mathrm{AD}$ in patients with DS. It has been shown that hypothyroidism is common in DS and that it is aggravated in patients that also present $\mathrm{AD}$. In conclusion, the study of these three conditions is important to understanding the reduced cognition in DS individuals in an effort to improve their quality of life.

Despite close similarities with late-onset $\mathrm{AD}$, individuals with $\mathrm{DS}$ respond differently to treatment, and a targeted approach to drug development is thus necessary. Genetic and preclinical studies offer opportunities for treatment development, and potential therapies have been identified using these approaches. 


\title{
Síndrome de Down: prevalência da doença de Alzheimer e o papel dos hormônios tireoidianos
}

\begin{abstract}
Resumo
A trissomia do cromossomo 21 causa a síndrome de Down (SD) e afeta cerca de um em 700 nascidos vivos nos Estados Unidos e 11,2 em dez mil nascidos vivos na Europa. Por quase um século, o nascimento de indivíduos com SD esteve associado à idade materna avançada, e agora os casos de maternidade tardia estão se tornando mais comuns. A SD é o distúrbio genético mais comum que causa incapacidade intelectual, e os avanços da ciência nos países desenvolvidos possibilitaram que as pessoas afetadas por essa síndrome vivessem mais, mas uma vida útil prolongada trouxe consigo a doença de Alzheimer (DA), que agrava a declínio cognitivo nesses indivíduos. O início da DA ocorre muito mais cedo em indivíduos com SD do que na população em geral. A DA é uma doença neurodegenerativa progressiva grave, que induz a diminuição da capacidade de memória e cognição. Vários genes importantes relacionados à DA são superexpressos na SD por causa do cromossomo extra. A produção de hormônios que são muito importantes para o desenvolvimento do sistema nervoso central, como os hormônios da tireoide, é afetada pela SD. Foi relatado que pacientes com DA apresentam alterações na homeostase dos hormônios da tireoide. Para compreender a DA na SD e tentar encontrar maneiras de melhorar a qualidade de vida desses indivíduos, o entendimento dessas três condições, SD, DA e homeostase do HT, é central para a obtenção de tratamentos eficazes que garantam o bem-estar do paciente.
\end{abstract}

\section{Palavras-chave}

Síndrome de Down. Doença de Alzheimer. Hormônio tireoidiano.

\section{Síndrome de Down: prevalencia de la enfermedad de Alzheimer y el papel de la hormona tiroidea}

\section{Resumen}

La trisomía del cromosoma 21 causa el síndrome de Down (SD) y afecta a aproximadamente uno de cada 700 nacidos vivos en los EE. UU. y a 11,2 de cada 10.000 nacidos vivos en Europa. Durante aproximadamente un siglo, el nacimiento de personas con SD se asoció con la edad materna avanzada y ahora los casos de maternidad tardía son cada vez más comunes. El SD es el trastorno genético más común que causa discapacidad intelectual 
y los avances en la ciencia en los países desarrollados han hecho posible que las personas afectadas por este síndrome vivan más tiempo, pero un período de vida prolongado ha traído consigo la enfermedad de Alzheimer (EA), que exacerba la deterioro cognitivo en estos individuos. La aparición de ED ocurre mucho antes en individuos con SD que en la población general. EA es una enfermedad neurodegenerativa progresiva severa, que induce la disminución de la capacidad de memoria y cognición. Varios genes importantes relacionados con EA están sobreexpresados en SD debido al cromosoma extra. La SD afecta la producción de hormonas que son muy importantes para el desarrollo del sistema nervioso central, como las hormonas tiroideas. Se ha informado que los pacientes con EA presentan cambios en la homeostasis de las hormonas tiroideas. Para comprender la EA en el SD y tratar de encontrar formas de mejorar la calidad de vida de estas personas, la comprensión de estas tres condiciones, SD, EA y la homeostasis HT, es fundamental para encontrar mejores tratamientos y mejorar el bienestar del paciente.

\section{Palabras clave}

Síndrome de Down. Enfermedad de Alzheimer. Hormona tiroidea.

\section{REFERENCES}

ALLDRED, J. M. et al. Expression profile analysis of hippocampal CA1 pyramidal neurons in aged Ts65Dn mice, a model of Down syndrome (DS) and Alzheimer's disease (AD). Brain Structure and Function, v. 220, n. 5, p. 2983-2996. 2015. DOI: 10.1007/ s00429-014-0839-0

ALZHEIMER'S ASSOCIATION. Alzheimer's disease facts and figures. Alzheimers Dement, v. 9, n. 2, p. 208-245, 2013. DOI: 10.1016/j.jalz.2013.02.003

ALZHEIMER'S ASSOCIATION. Alzheimer's disease facts and figures. Alzheimers Dement, v. 14, n. 3, p. 367-429, 2018. DOI: 10.1016/j.jalz.2018.02.001

ANDERSEN, S. L. et al. Smoking reduces the risk of hypothyroidism and increases the risk of hyperthyroidism: evidence from 450.842 mothers giving birth in Denmark. Clinical Endocrinology, v. 80, p. 307-314, 2014. DOI: 10.1111/cen.12279

ANNUS, T. et al. The pattern of amyloid accumulation in the brains of adults with Down syndrome. Alzheimers Dement, v. 12, p. 538-545, 2016. DOI: 10.1016/j. jalz.2015.07.490

BÉGIN, M. E. et al. Thyroid function and cognition during aging. Current Gerontology and Geriatrics Research, v. 2008, n. 474868, p. 1-11, 2018. DOI: 10.1155/2008/474868 
BERGER, A. L. Insulin resistance and reduced brain glucose metabolism in the etiology of Alzheimer's disease. Journal of Insulin Resistance, v. 1, n. 1, p. 2-7, 2016. DOI: 10.4102/jir.v1i1.15

BERNAL, J. Thyroid hormone receptors in brain development and function. Nature Clinical Practice Endocrinology \& Metabolism, v. 3, n. 3, p. 249-259, 2007. DOI: 10.1038/ncpendmet0424

BHAUMIK, S. et al. Effect of thyroid stimulating hormone on adaptive behavior in Down's syndrome. Journal of Mental Deficiency Research, v. 35, p. 512-520, 1991. DOI: 10.1111/j.1365-2788.1991.tb00448.x

BULL, M. J.; COMMITTEE ON GENETICS. Health supervision for children with Down syndrome. Pediatrics, v. 128, n. 2, p. 393-406, 2011. DOI: 10.1542/peds.2011-1605

BUTTERFIELD, D. A.; HALLIWELL, B. Oxidative stress, dysfunctional glucose metabolism and Alzheimer disease. Nature Reviews Neuroscience, v. 20, p. 148-160, 2019. DOI: 10.1038/s41583-019-0132-6

CARMONA-IRAGUI, M. et al. Down syndrome, Alzheimer disease, and cerebral amyloid angiopathy: the complex triangle of brain amyloidosis. Developmental Neurobiology, v. 79, n. 7, p. 716-737, 2019. DOI: 10.1002/dneu.22709

CATALDO, A. M. et al. Endocytic pathway abnormalities precede amyloid $\beta$ deposition in sporadic Alzheimer's disease and Down syndrome. The American Journal of Pathology, v. 157, n. 1, p. 277-286, 2000. DOI: 10.1016/s0002-9440(10)64538-5

CONTRERAS-JURADO, C.; PASCUAL, A. Thyroid hormone regulation of APP ( $\beta$-amyloid precursor protein) gene expression in brain and brain cultured cells. Neurochemistry International, v. 60, n. 5, p. 484-487, 2012. DOI: 10.1016/j.neuint.2012.01.027

CORREIA, S. C. et al. Mitochondrial importance in Alzheimer's, Huntington's and Parkinson's diseases. Advances in Experimental Medicine and Biology, v. 724, p. 205-221, 2012. DOI: $10.1007 / 978-1-4614-0653-2 \_16$

DAVIS, J. D. et al. Thyroid hormone levels in the prefrontal cortex of post-mortem brains of Alzheimer's disease patients. Current Aging Science, v. 1, n. 3, p. 175-181, 2008. DOI: $10.2174 / 1874609810801030175$

DE GRAAF, G. et al. Estimates of the live births, natural losses, and elective terminations with Down syndrome in the United States. American Journal of Medical Genetics, v. 167A, n. 4, p. 756-767, 2015. DOI: 10.1002/ajmg.a.37001

DE GRAAF, G. et al. Estimation of the number of people with Down syndrome in the United States. Genetics in Medicine, v. 19, n. 4, p. 439-447, 2017. DOI: 10.1038/ $\operatorname{gim} .2016 .127$

DE JONG, F. J. et al. Thyroid hormones, dementia, and atrophy of the medial temporal lobe. The Journal of Clinical Endocrinology \& Metabolism, v. 91, n. 7, p. 2569-2573, 2006. DOI: $10.1210 /$ jc.2006-0449 
DE SOUZA, J. S. et al. The hypothyroid brain. Receptors \& Clinical Investigation, v. 3, p. e1408, 2016. DOI: 10.14800/rci.1408

DI DOMENICO, F. et al. Bach1 overexpression in down syndrome correlates with the alteration of the HO-1/BVR-A system: insights for transition to Alzheimer Disease. Journal Alzheimer's Disease, v. 44, n. 4, p. 1107-1120, 2015. DOI: 10.3233/JAD-141254

DIÉGUEZ, M. et al. Prevalence of thyroid dysfunction in women in early pregnancy: does it increase with maternal age? Clin Endocrinol, v. 84, n. 1, p. 121-126, 2015. DOI: 10.1111/cen.12693

FLAMANT, F. et al. Genetic investigation of thyroid hormone receptor function in the developing and adult brain. Current Topics in Developmental Biology, v. 125, p. 303335, 2017. DOI: 10.1016/bs.ctdb.2017.01.001

FRIESEMA, E. C. Thyroid hormone transporters. Vitamins and Hormones, v. 70, p. 137-167, 2005. DOI: 10.1016/S0083-6729(05)70005-4

FU, A. L. et al. Thyroid hormone prevents cognitive deficit in a mouse model of Alzheimer's disease. Neuropharmacology, v. 58, n. 4-5, p. 722-729, 2010. DOI: 10.1016/j.neuropharm.2009.12.020

GLIVETIC, T. et al. Prevalence, prenatal screening and neonatal features in children with Down syndrome: a registry-based national study. Italian Journal of Pediatrics, v. 41, p. 81, 2015. DOI: 10.1186/s13052-015-0192-9

HARPER, P. C.; ROE, C. M. Thyroid medication use and subsequent development of dementia of the Alzheimer type. Journal of Geriatric Psychiatry and Neurology, v. 23, p. 63-69, 2010. DOI: 10.1177/0891988709342723

HARVEY, C. B.; WILLIAMS, G. Mechanism of thyroid hormone action. Thyroid, v. 12, p. 44-46, 2002. DOI: 10.1089/105072502760143791

HEAD, E. et al. Aging in Down syndrome and the development of Alzheimer's disease neuropathology. Current Alzheimer Research, v. 13, n. 1, p. 18-29, 2016. DOI: 10.217 4/1567205012666151020114607

HEUER, H. The importance of thyroid hormone transporters for brain development and function. Best Pratice \& Research: Clinical Endocrinology \& Metabolism, v. 21, p. 265-276, 2007. DOI: 10.1016/j.beem.2007.03.003

JUNG, M. S. et al. Regulation of RCAN1 protein activity by Dyrk1A protein-mediated phosphorylation. Journal of Biological Chemistry, v. 286, n. 46, p. 40401-40412, 2011. DOI: $10.1074 / j b c . M 111.253971$

KAPADIA, R. et al. Mechanisms of anti-inflammatory and neuroprotective actions of PPAR-gamma agonists. Frontiers in Bioscience, v. 1, n. 13, p. 1813-1826, 2008. DOI: $10.2741 / 2802$ 
KIM, M. K. et al. In vivo transcription factor recruitment during thyroid hormone receptor-mediated activation. Proceedings of the National Academy of Sciences of the United States American, v. 96, n. 18, p. 10092-10097, 1999. DOI: 10.1073/pnas.96. 18.10092

KUMAR, A. et al. A review on Alzheimer's disease pathophysiology 4 and its management: an update. Pharmacological Reports, v. 67, n. 2, p. 195-203, 2015. DOI: 10.1016/j. pharep.2014.09.004

LEVERENZ, J. B.; RASKIND, M. A. Early amyloid deposition in the medial temporal lobe of young down syndrome patients: a regional quantitative analysis. Experimental Neurology, v. 150, p. 296-304, 1998. DOI: 10.1006/exnr.1997.6777

LIN, M. T.; BEAL, M. F. Mitochondrial dysfunction and oxidative stress in neurodegenerative diseases. Nature, v. 443, n. 7113, p. 787-795, 2006. DOI: 10.1038/nature05292

LIU, C. C. et al. Neuronal LRP1 regulates glucose metabolism and insulin signaling in the brain. Journal of Neuroscience, v. 35, p. 5851-5859, 2015. DOI: 10.1523/JNEUROSCI.5180-14.2015

LOTT, I. T.; HEAD, E. Dementia in Down syndrome: unique insights for Alzheimer disease research. Nature Reviews Neurology, v. 15, p. 135-147, 2019. DOI: 10.1038/ s41582-018-0132-6

MENDES-DE-AGUIAR, C. B. et al. Thyroid hormone increases astrocytic glutamate uptake and protects astrocytes and neurons against glutamate toxicity. Journal of Neuroscience Research, v. 86, p. 3117-3125, 2008. DOI: 10.1002/jnr.21755

MOK, K. Y. et al. Polymorphisms in BACE2 may affect the age of onset Alzheimer's dementia in Down syndrome. Neurobiology of Aging, v. 35, p. 1513.e1-5, 2013. DOI: 10.1016/j.neurobiolaging.2013.12.022

MOOG, N. K. et al. Influence of maternal thyroid hormones during gestation on fetal brain development. Neuroscience, v. 342, p. 68-100, 2015. DOI: 10.1016/j.neuroscience.2015.09.070

MORTE, B.; BERNAL, J. Thyroid hormone action: astrocyte-neuron communication. Frontiers in Endocrinology, v. 5, p. 82, 2014. DOI: 10.3389/fendo.2014.00082

PAGANO, G.; CASTELLO, G. Oxidative stress and mitochondrial dysfunction in Down syndrome. Advances in Experimental Medicine and Biology, v. 724, p. 291-299, 2012. DOI: 10.1007/978-1-4614-0653-2_22

PARKER, S. E. et al. Updated national birth prevalence estimates for selected birth defects in the United States, 2004-2006. Birth Defects Research Part A: Clinical and Molecular Teratology, v. 88, n. 12, p. 1008-1016, 2010. DOI: 10.1002/bdra.20735

PATEL, J. et al. Thyroid hormones and fetal neurological development. Journal of Endocrinology, v. 209, n. 1, p. 1-8, 2011. DOI: 10.1530/JOE-10-0444 
PENNINGTON, B. F. et al. The neuropsychology of Down syndrome: evidence for hippocampal dysfunction. Child Development, v. 74, n. 1, p. 75-93, 2003. DOI: $10.1111 / 1467-8624.00522$

PERLUIGI, M. et al. Unraveling the complexity of neurodegeneration in brain of subjects with Down syndrome: insights from proteomics. Proteomics Clin Appl, v. 8, n. 0, p. 73-85, 2014. DOI: 10.1002/prca.201300066

PUESCHEL, S. M. Do Olmec figures resemble children with specific dysmorphology syndromes? Journal of the History of Medicine and Allied Sciences, v. 53, p. 407-415, 1998.

RAY, A. et al. Maternal telomere length and risk of Down syndrome: epidemiological impact of smokeless chewing tobacco and oral contraceptive on segregation of chromosome 21. Public Health Genomics, v. 19, n. 1, p. 11-18, 2016. DOI: 10.1159/000439245

REGER, M. A. et al. Effects of intranasal insulin on cognition in memory-impaired older adults: modulation by APOE genotype. Neurobiology of Aging, v. 27, n. 3, p. 451-458, 2006. DOI: 10.1016/j.neurobiolaging.2005.03.016

REITZ, C. et al. Epidemiology of Alzheimer's disease. Nature Reviews Neurology, v. 7, n. 3, p. 137-152, 2011. DOI: 10.1038/nrneurol.2011.2

ROIZEN, N. J.; PATTERSON, D. Down's syndrome. Lancet, v. 361, n. 9365, p. 12811289, 2003. DOI: 10.1016/S0140-6736(03)12987-X

ROPER, R. J.; REEVES, R. H. Understanding the basis for Down syndrome phenotypes. PLoS Genetics, v. 2, n. 3, p. e50, 2006. DOI: 10.1371/journal.pgen.0020050

ROVET, J. F. The role of thyroid hormones for brain development and cognitive function. Endocr. Dev., v. 26, p. 26-43, 2014. DOI: 10.1159/000363153

SALAMEH, T. S. et al. Insulin resistance, dyslipidemia, and apolipoprotein E interactions as mechanisms in cognitive impairment and Alzheimer's disease. Experimental Biology andMedicine, v. 241, n. 15, p. 1676-1683, 2016. DOI: 10.1177/1535370216660770

SATO, N.; MORISHITA, R. The roles of lipid and glucose metabolism in modulation of $\beta$-amyloid, tau, and neurodegeneration in the pathogenesis of Alzheimer's disease. Frontiers in Aging Neuroscience, v. 7, p. 199, 2015. DOI: 10.3389/fnagi.2015.00199

STURGEON, X.; GARDINER, K. J. Transcript catalogs of human chromosome 21 and orthologous chimpanzee and mouse regions. Mammalian Genome, v. 22, n. 5-6, p. 261-271, 2011. DOI: 10.1007/s00335-011-9321-y

SULLIVAN, S. E.; YOUNG-PEARSE, T. Induced pluripotent stem cells as a discovery tool for Alzheimer's disease. Brain Research, v. 1656, p. 742-748, 2017. DOI: 10.1016/j. brainres.2015.10.005

SUN, X. et al. Regulator of calcineurin 1 (RCAN1) facilitates neural apoptosis through caspase-3 activation. Journal of Biology Chemistry, v. 286, n. 11, p. 9049-9062, 2011. DOI: $10.1074 / j b c . M 110.177519$ 
UMEGAKI, H. Neurodegeneration in diabetes mellitus. Advances in Experimental Medicine and Biology, v. 724, p. 258-265, 2012. DOI: 10.1007/978-1-4614-0653-2_19

VASSAR, R. et al. Function, therapeutic potential and cell biology of BACE proteases: current status and future prospects. Journal of Neurochemistry, v. 130, n. 1, p. 4-28, 2014. DOI: $10.1111 /$ jnc. 12715

VIRJI-BABUL, N. et al. Use of health care guidelines in patients with Down syndrome by family physicians across Canada. Paediatrics \& Child Health, v. 12, n. 3, p. 179-183, 2007.

WANG, X. et al. Oxidative stress and mitochondrial dysfunction in Alzheimer's disease. Biochimica et Biophysica Acta, v. 1842, n. 8, p. 1240-1247, 2014. DOI: 10.1016/j. bbadis.2013.10.015

WHOOTEN, R. et al. Endocrine manifestations of Down syndrome. Current Opinion in Endocrinology, Diabetes and Obesity, v. 25, n. 1, p. 61-66, 2018. DOI: 10.1097/ MED.0000000000000382

WU, Y. et al. Regulation of global gene expression and cell proliferation by APP. Scientific Reports, v. 6, 2016. DOI: 10.1038/srep22460

ZHANG, N. et al. A pilot study on the relationship between thyroid status and neuropsychiatric symptoms in patients with Alzheimer disease. Chinese Medical Journal, v. 125, n. 18, p. 3211-3216, 2012. 